\title{
Lycopene: Is it Beneficial to Human Health as an Antioxidant?
}

\author{
Likopen: Antioksidan Olarak Insan Sağlığına Faydalı mı?
}

\author{
Merve BACANLI ${ }^{1 *}$, Nurşen BAŞARAN ${ }^{1}, A$. Ahmet BAŞARAN ${ }^{2}$ \\ 'Hacettepe University, Faculty of Pharmacy, Department of Pharmaceutical Toxicology, Ankara, Turkey \\ ${ }^{2}$ Hacettepe University, Faculty of Pharmacy, Department of Pharmacognosy, Ankara, Turkey
}

\begin{abstract}
It is well known that free oxygen radicals play an important role in the pathogenesis of several chronic disorders. Antioxidants are known as potential scavengers of reactive oxygen species that can protect biologic membranes against oxidative damage. Recent interest in phytochemicals has increased because of their protective effects against free oxygen radicals. Lycopene, which belongs to the carotenoid family, is the most effective singlet oxygen scavenger in vitro of all the carotenoids. Foods that contain lycopene and related supplements have been reported to prevent chronic diseases including cancer, asthma, and cardiovascular disorders. The aim of the article was to give a brief review of the antioxidant properties and beneficial health effects of lycopene.
\end{abstract}

Key words: Lycopene, antioxidant, health effects

öz

Birçok kronik hastalığın patogenezinde serbest oksijen radikallerinin önemli rol oynadığı bilinmektedir. Antioksidanlar reaktif oksijen türevlerinin olası süpürücüleri olarak bilinir, bu nedenle biyolojik membranları oksidatif hasara karşı koruyabilirler. Serbest oksijen radikallerine karşı koruyucu etkileri nedeniyle fitokimyasallara ilgi giderek artmaktadır. Karetonoid ailesinde yer alan likopen tüm karotenoidler içerisinde in vitro şartlarda en etkili tekli oksijen süpürücüsüdür. Likopen içeren gıdalar ve likopen desteklerinin kanser, astım ve kardiyovasküler hastalıklar gibi kronik hastalıklara karşı koruyucu etkilerinin bulunduğu rapor edilmiştir. Bu makalede likopenin antioksidan özellikleri ve sağlığa yararlı etkilerine ilişkin bir özet verilmesi amaçlanmıştır.

Anahtar Kelimeler: Likopen, antioksidan, sağlık etkileri

\section{INTRODUCTION}

It is well known that free oxygen radicals play important roles in the pathogenesis of several chronic disorders such as cancer, diabetes, and cardiovascular and neurologic diseases.1.2

Antioxidants are known as potential scavengers of reactive oxygen species (ROS) that protect biologic membranes against oxidative damage. If the balance between free radicals and antioxidant defense is destroyed by chemicals, the imbalance may lead to damage to DNA, lipids, and proteins. ${ }^{3}$ The role of oxidative stress induced by ROS and the oxidative damage of important biomolecules are the main focuses of research related to human diseases. ${ }^{4}$

Recent interest in phytochemicals, especially plant phenolics, has increased because of their protective effects against free oxygen radicals. Phenolic compounds are secondary metabolites that are derivatives of the pentose phosphate, shikimate, and phenylpropanoid pathways in plants., 5 They contribute to the sensory qualities of fruits and vegetables: color, astringency, bitterness, and aroma.?

It is estimated that approximately $50 \%$ of cancer cases and $35 \%$ of cancer deaths in the United States can be attributed to poor diet. ${ }^{8}$ Many studies showed that fruit and vegetable-rich diets were associated with a decreased risk of chronic diseases. ${ }^{9}$

Carotenoids, which produce colors ranging from yellow to red, are synthesized by plants and microorganisms. ${ }^{10}$ More than 700 carotenoids have been identified, about 40 of which are present in the human diet, and about 20 have been identified in blood and tissues. ${ }^{11,12} \beta$-carotene, $\alpha$-carotene, lycopene, $\alpha$-cryptoxanthine, lutein and zeoxanthin are the main carotenoids in the human $\operatorname{diet}^{12,13}$

Lycopene (Figure 1), a noncyclic carotenoid found in tomatoes (Solanum lycopersicum, Solanaceae), has received considerable scientific interest in recent years. Red-colored fruits and vegetables are the main sources of lycopene in the human diet, 
although not all red-colored plants contain lycopene. Its main function is to absorb light during photosynthesis and to protect plants against photosensitization. ${ }^{10}$

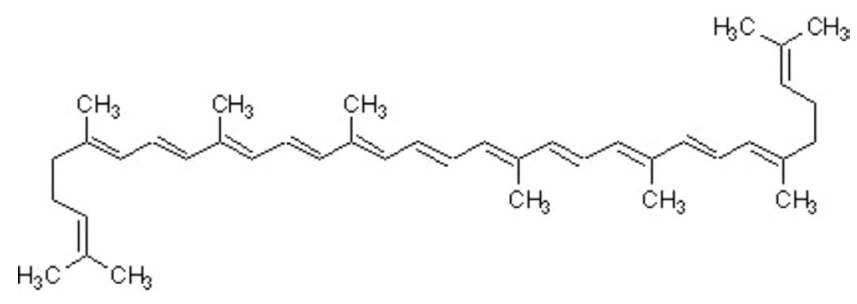

Figure 1. Lycopene

This article mainly focuses on the protective effects of lycopene against chronic diseases, and the chemistry and sources, dietary intake, mechanism of action, bioavailability, and pharmacokinetics of lycopene will also be discussed.

\section{DATA COLLECTION}

Information about lycopene was obtained from a literature search of electronic databases such as Google Scholar, PubMed, and Scopus for publications on health beneficial effects of lycopene. Lycopene, antioxidant, tomato lycopene, and lycopene and health were used as key terms.

\section{Chemistry and sources of lycopene}

Lycopene is found in processed tomato products, watermelon, pink grapefruits, papaya, and apricot.19 Its chemical structure is an open chain hydrocarbon containing 11 conjugated and 2 non-conjugated double bonds arranged in a linear array. During chemical reactions, light or thermoenergy, these bonds can undergo isomerization from trans to mono or poly cis-isomers. It lacks a $\beta$-ionene ring structure and has no provitamin $A$ activity, but exhibits a physical quenching rate constant with singlet oxygen $\left({ }^{1} \mathrm{O}_{2}\right)$ almost twice as high as that of $\beta$-carotene. Its molecular formula is $\mathrm{C}_{40} \mathrm{H}_{56}$ and it has all-trans, 5-cis, 9-cis, 13-cis and 15-cis isoforms. ${ }^{19}$ The trans isoform is commonly found in the human diet and the cis isoform is found in human blood, plasma, breast milk, and human tissues. ${ }^{22-25}$ The color of lycopene is related to its isomeric form. ${ }^{22}$ Antioxidant potential of lycopene isomers are 5-cis>9-cis>7-cis>13-cis>15-cis>11cis〉all-trans, respectively. ${ }^{26}$

\section{Dietary intake levels of lycopene}

The United States Food and Drug Administration in America granted Generally Recognized as Safe status to lycopene as a nutritional supplement. ${ }^{10}$ Dietary intake of lycopene varies due to populations. Lycopene intake in Italy with an average intake of $7.4 \mathrm{mg} /$ day is greater than in other countries. ${ }^{14}$ The average intake of lycopene is $6.6-10.5 \mathrm{mg} /$ day for men and $5.7-10.4 \mathrm{mg} /$ day for women in the United States, $1.1 \mathrm{mg} /$ day in the United Kingdom, $1.6 \mathrm{mg} /$ day in Spain, $3.8 \mathrm{mg} /$ day in Austria, $4.8 \mathrm{mg} /$ day in France, and $4.9 \mathrm{mg} /$ day in the Netherlands. ${ }^{15,16}$
For many years, lycopene containing foods and lycopene supplements have been used without any safety problems. Rao and Agarwal ${ }^{17}$ (1998) demonstrated that lycopene intake levels varied from 5 to $75 \mathrm{mg} / \mathrm{day}$ in tomato juice, tomato sauce, and nutritional supplements in healthy humans. No adverse effects due to lycopene consumption were observed. Similarly, no evidence of toxic effects of lycopene were seen with two synthetic crystalline lycopene (BASF lycopene 10 CWD and Lyco Vit $10 \%$, each containing approximately $10 \%$ lycopene $)^{18}$ and lycopene derived from a fungal biomass of Blakeslea trispos, suspended in sunflower oil in rats. ${ }^{19}$ No teratogenic effects were also observed in a two-generation rat study. ${ }^{20}$

\section{Bioavailability and kinetics of lycopene}

Lycopene bioavailability can be affected by many factors such as food processing and dietary composition. ${ }^{21}$ Food processing in particular and thermal processing may improve lycopene bioavailability by breaking down cell walls, which weakens the bonding forces between lycopene and the tissue matrix, thus making lycopene more accessible and enhancing the cis-isomerization. The bioavailability of cis-isomers in food is higher than that of all-trans isomers.

The amount of lycopene present in processed tomato products is often much higher in fresh tomatoes given that processing often involves concentrations via water loss. Multiple studies have shown that lycopene from thermally processed tomato products was more bioavailable than lycopene from fresh tomatoes. ${ }^{22}$ Ketchup contains 9.9-13.44 mg lycopene/100 g, whereas fresh tomatoes contain 0.88-7.44 mg lycopene/100 g wet weight. ${ }^{23,24}$

Lycopene bioavailability is also greatly affected by dietary composition. Consuming lycopene with fat increases its bioavailability because lycopene is a lipid-soluble compound. For example, consuming salads with full-fat dressing results in higher blood carotenoid levels than eating salads with reduced fat dressing. When salads were consumed without fat in the same study, no measurable lycopene uptake occurred. ${ }^{25}$ The consumption of tomato salsa with avocado (as lipid source) led to a 4.4-fold increase in lycopene absorption as compared with salsa without avocado. ${ }^{26}$

It is believed that lycopene was absorbed by passive diffusion as lipids. Many studies suggested that lycopene absorption may be facilitated by other transporters, but this has not yet been confirmed. ${ }^{27,28}$ Competition by other carotenoids or cholesterol may also influence lycopene absorption. ${ }^{16}$ Age, sex, hormonal status, body mass and composition, blood lipid levels, smoking and alcohol may influence the absorption of lycopene. ${ }^{29}$ Lycopene is found in the highest concentrations in the liver, testes, adrenal glands, and adipose tissues. It is found in lower concentrations in the kidney, ovary, lung, and prostate. ${ }^{30}$

Very little is known about the in vivo metabolism of lycopene. Only a few metabolites, such as 5,6-dihydroxy-5,6-dihydro lycopene, have been detected in human plasma. It is suggested that lycopene may undergo in vivo oxidation to form epoxides, which then may be converted to the polar 5,6-dihydoxy-5,6dihydrolycopene through metabolic reduction. ${ }^{31}$ In humans, 
lycopene absorption is in the range of $10-30 \%$, with the remainder being excreted. ${ }^{17,29}$

\section{Health protective effects of lycopene}

The biologic activities of carotenoids depend on their provitamin A activity, but lycopene does not have provitamin activity due to the lack of a $\beta$-ionic ring structure. ${ }^{32}$ The main biologic activity of lycopene is thought be its antioxidant properties. It is the most effective ${ }^{1} \mathrm{O}_{2}$ scavenger in vitro of all the carotenoids. ${ }^{33}$

Increasing clinical evidence supports the role of lycopene as a micronutrient with important health benefits because it is suggested to play a role in disorders related to oxidative stress and cancer. It is a highly efficient antioxidant with a ${ }^{1} \mathrm{O}_{2}$ and has free radical scavenging capacity. Lycopene can scavenge oxygen radicals, reduce oxidative stress, and prevent ROS generation. It may protect against the in vivo oxidation of lipids, proteins, and DNA. ${ }^{34,35}$

Inhibition of insulin-like growth factor-I and androgen signaling, interleukin-6 expression, improving immune responses and gap junction communication (GJC), induction of phase II drug metabolizing enzymes and oxidative defense genes are the important suggested non-oxidative mechanisms of action of lycopene. ${ }^{36}$

Human tumors are generally deficient in GJC and its upregulation is associated with the decreased proliferation of tumor cells. Thereby, improving GJC is a suggested mechanism in the prevention of cancers. With this effect, lycopene could be an anticarcinogenic compound. 10,37 Suppression of the carcinogeninduced phosphorylation of regulatory proteins such as p53 and $\mathrm{Rb}$ antioncogenes by lycopene may also play an important role in the suppression of cell division at the G-G1 cell cycle phase. ${ }^{38}$

Lycopene acts as a hypocholesterolemic agent by inhibiting 3-hydroxy-3-methylglutaryl-coenzyme A reductase. This mechanism may be associated with the reduction of risk of cardiovascular diseases. ${ }^{39}$ In experimental animals, lycopene induced immunoenhancement. ${ }^{40}$ The increase in the phenotypic and functional maturation of dendritic cells by lycopene was also reported. ${ }^{41}$

\section{Cancer}

The consumption of tomatoes and tomato products has been associated with a reduced risk of a number of different types of cancers. ${ }^{42}$ A study of older Americans indicated that a high intake of tomatoes was associated with a significant reduction in mortality from cancers of all sites..$^{43,44}$ In the Mediterranean, the incidence of cancer is lower due to the rich diet in tomatoes and tomato products. ${ }^{45}$

It has been shown that lycopene reduced the oxidative injury by stimulating the levels and activities of antioxidant enzymes including glutathione (GSH), glutathione-S-transferases, and glutathione peroxidase in animals with gastric cancer. ${ }^{46}$ Lycopene prevents the oxidative damage of DNA, lipids, and proteins. ${ }^{47}$ It modulates immune function, and induces apoptotic cell death. ${ }^{10}$ It is also suggested to inhibit ROS production and decrease the phosphorylation of extracellular signal-regulated kinase (ERK), which results in the inhibition of cancer cell growth. 34,48,49 Lycopene inhibited phosphorylation of ERK, which is a major regulator of cell proliferation, apoptosis, and differentiation in gastric cells, as well as hepatocarcinoma cells.

Lycopene also decreased $\mathrm{Bcl}-2$ and increased levels of $\mathrm{Bax}$, which induce the release of cytochrome $\mathrm{C}$ and other proapoptotic factors from mitochondria, leading to apoptosis. Bcl-2 is an important anti-apoptotic protein that regulates cell death. $\mathrm{Bcl}-2$ inhibits apoptosis by reducing caspase activation such as caspase 3 and 8 . Bax protein, a member of the Bcl-2 family of proteins, is a regulator of apoptosis and promotes apoptosis. ${ }^{50,51}$ Lycopene treatment inhibited cancer cell proliferation by increasing cell cycle arrest in the G0-G1 phase. ${ }^{52}$

Lycopene supplementation prevented changes in p53 expression in gastric mucosa of ferrets and it was suggested that lycopene may protect against the development of gastric cancer by inhibiting p53 dependent apoptosis and providing the balance of apoptosis and cell proliferation. Lycopene also prevented changes in p53 overexpression in gastric mucosa exposed to cigarette smoke. ${ }^{53}$ The main evidence in support of the role of lycopene in the prevention of these cancers comes from cell culture, animal, and epidemiologic studies. ${ }^{10}$

Of all cancers, the role of lycopene in the prevention of prostate cancer has been studied the most. ${ }^{10}$ Hall ${ }^{54}$ (1996) and KotakeNara et al. ${ }^{55}$ (2001) demonstrated that lycopene inhibited the growth of DU145 prostate cancer cells. Similar to these studies, Kim et al. ${ }^{56}$ (2002) showed the protective effects of lycopene as an antioxidant on LNCaP prostate cancer cells growth. The effect of whole tomato powder (13 $\mathrm{mg}$ lycopene per $\mathrm{kg}$ diet), lycopene beadlets (161 mg lycopene per kg diet), and control beadlets ( $0 \mathrm{mg}$ lycopene per $\mathrm{kg}$ diet) were evaluated for their effect on prostate cancer in a rat model. The study showed that the consumption of tomato powder, but not lycopene, inhibited prostate carcinogenesis. ${ }^{57}$ In a cohort study, Seventh-Day Adventist men who consumed high levels of tomato products more than five times per week had significantly decreased risk of prostate cancer compared with men who consumed lower amounts of tomato products less than once per week. ${ }^{58}$ In another study, lycopene induced the apoptosis of pancreatic cancer cells by suppressing the expression of survivin, clAP1, and cIAP2. Lycopene may be a promising therapeutic agent for human pancreatic cancer. ${ }^{59}$

Gastric (stomach) cancer remains as one of the major causes of cancer death in the world. ${ }^{60,61}$ Dietary factors are believed to play an important role in the prevention of gastric cancer, among which dietary carotenoids have received considerable interest. ${ }^{62-64}$ Inverse associations between tomato or lycopene consumption (intake) and gastric cancer risk were observed in a variety of populations. ${ }^{44,65-76} \mathrm{~A}$ suggestive, but not statistically significant, inverse association was observed in a study conducted in Belgium with 449 subjects even though the study population had a low consumption of tomatoes. ${ }^{74}$ In an ecologic study, plasma levels of various nutrients in samples of Japanese populations in various regions were evaluated and the lowest gastric cancer rates were found in regions higher 
in plasma lycopene, whereas regions low in lycopene had the highest rates. ${ }^{77}$ Ito et al. ${ }^{78}$ (2005) examined cancer mortality and serum levels of carotenoids, retinol and tocopherol, in the inhabitants of a rural area of Japan and found that serum levels of lycopene were associated with a reduced risk of death from stomach cancer. They suggested that lycopene may be a promising biomarker to predict mortality related with stomach cancer.

It has been concluded that consumption of lycopenecontaining foods may decrease for risk of breast cancers. Cui et al. ${ }^{79}$ (2008) found that lycopene consumption was inversely associated with estrogen and progesterone receptor positive breast cancer risk in postmenopausal women. Lung cancer is the leading cause of cancer death for both men and women. Epidemiological studies suggest that higher intake of lycopene is associated with either a reduced risk of lung $\operatorname{cancer}^{80}$, or no change in lung cancer risk, as compared with lower intake levels. ${ }^{81}$ The protective effects against ovarian cancer, colorectal cancer, and pancreatic cancer were demonstrated in different epidemiologic studies. ${ }^{16}$

\section{Cardiovascular diseases}

Cardiovascular disease is a leading cause of death in America and the Western world. ${ }^{82}$ Oxidation of low-density lipoprotein (LDL) is the main mechanism of cardiovascular diseases. Thus, antioxidants may have an effect in reducing LDL oxidation. Due to this effect, lycopene may be beneficial in cardiovascular diseases as an antioxidant. ${ }^{83}$

Low plasma lycopene levels were reported by many researchers in hypertension, myocardial infarction, stroke, and atherosclerosis. ${ }^{84}$ Lycopene was decreased in carotid artery intima-media thickness. ${ }^{85}$ Some clinical trials have also supported a relationship between cardiovascular disease and lycopene intake. In a study, 19 healthy subjects consumed placebo (0 mg lycopene), tomato juice (50.4 mg lycopene), spaghetti sauce (39.2 mg lycopene), and tomato oleoresin (75 mg lycopene) treatment daily for one week and went through a one-week washout period between each treatment week. The serum lycopene concentration doubled in subjects on lycopenecontaining treatments and also a significant decrease in serum lipid peroxidation and LDL oxidation was observed after subjects consumed any one of the three lycopene-containing treatments. ${ }^{86}$ In an another study, healthy individuals received one of three tomato treatments for 15 days (condensed tomato soup, ready-to-serve tomato soup, or $V 8^{\circledR}$ vegetable juice). Blood samples were taken at baseline and after treatment. A measure of protection against oxidative stress was significantly increased in all three treatment groups. ${ }^{87}$ Shen et al. ${ }^{88}$ (2007) treated 24 subjects with either fresh tomato, tomato juice, or a lycopene drink (all delivering $40 \mathrm{mg}$ lycopene/day) for six weeks. It was found that triglyceride levels and LDL were decreased, and high-density lipoprotein (HDL) increased in subjects who consumed fresh tomato and tomato juice. ${ }^{88}$ Bohn et al. ${ }^{89}$ (2009) demonstrated that soy tomato beverage consumption significantly reduced LDL+VLDL levels and increased HDL levels in 18 healthy men and women.

\section{Neurodegenerative diseases}

The high lipid content of the nervous system, low antioxidant capacity, and the presence of iron, coupled with its high aerobic metabolic activity, make it particularly susceptible to oxidative damage. ${ }^{90}$ Most studies have shown the effects of antioxidants on nervous system disorders including Alzheimer's disease, Huntington's disease, and Parkinson disease. ${ }^{91}$ In an animal study, a beneficial effect of lycopene supplementation in rotenone-induced Parkinson's disease was demonstrated. ${ }^{92}$ Lycopene showed protective effects against myeloid $\beta$-induced neurotoxicity in cultured rat cortical neurons ${ }^{93}, 3$-nitropropionic acid-induced mitochondrial oxidative stress, and dysfunctions in nervous system ${ }^{94}$, and trimethyltin-induced neurotoxicity in primary cultured rat hippocampal neurons. ${ }^{95}$

\section{Gastrointestinal diseases}

A significant increase has been seen in peptic ulcer incidence worldwide. The generation of ROS is the major cause of stressinduced ulcers. ${ }^{96}$ Therefore, it is suggested that powerful antioxidants may be useful in the treatment of ulcers. ${ }^{97}$ Accordingly, to overcome the adverse effects of drugs and provide efficacious and safe therapy, herbal antioxidants may be useful due to their antioxidant effects. ${ }^{98}$ The anti-ulcer activity of lycopene can be attributed to different mechanisms, including inhibition of gastric acid secretion, reinforcement of the gastric mucosal barrier, and its free radical scavenging activity. ${ }^{99}$ It has been shown that lycopene $(2 \mathrm{mg} / \mathrm{kg})$ and hesperidin $(100 \mathrm{mg} / \mathrm{kg})$ decreased gastric secretions and total acidity as well as increased gastric $\mathrm{pH}$ due to the restoration of normal gastric conditions in ulcer-induced rats. ${ }^{98}$ Similarly, Boyacioglu et al. ${ }^{13}$ (2016) demonstrated that lycopene treatment exhibited protection against indomethacin-induced gastric ulcer in rats in a dose-dependent manner. In the same study, it was demonstrated that superoxide dismutase (SOD) activity and GSH levels were higher in the lycopene-treated group, and catalase (CAT) activity and malondialdehyde (MDA) levels were lower in the lycopene-treated group when compared with controls. These results suggest that lycopene had antioxidant effects on the treatment of ulcers. ${ }^{13}$

Helicobacter pylori is an important risk factor for chronic gastritis, peptic ulcer, and gastric carcinoma. In H. pylori-induced gastric injury, ROS is the major toxic factor. ${ }^{100}$ Lycopene is reported to have a significant inhibitory effect on gastric acid secretion followed by efficacy against $H$. pylori infections..$^{101-103}$ Jang et al. ${ }^{100}$ (2012) showed that lycopene rescued the H. pylori-infected cells from DNA damage and apoptosis in gastric epithelial cells. It also inhibited $H$. pylori-induced increases in ROS production and alterations in the cell cycle. ${ }^{100}$

Gastroesophageal reflux disease (GERD) commences due to reflux of gastric content into the esophagus, which results in mucosal devastation. ${ }^{104}$ ROS play an important role in the pathogenesis of GERD. ${ }^{105}$ In rats, lycopene $(50$ and $100 \mathrm{mg} / \mathrm{kg}$ ) showed significant protection against experimental esophagitis. The gastric content is a major factor in the pathogenesis of GERD and it is claimed that lycopene decreased the acidity (total and free) and gastric volume, and thereby subsequently 
increased the $\mathrm{pH}$. Modulation in $\mathrm{pH}$ and acidity of gastric content after lycopene treatment was also reflected through a decrease in esophagitis indices. In the same study, a positive modulation in GERD by lycopene was seen in physiologic changes. Similar to other studies, it was shown that SOD and CAT enzyme activities and GSH levels were higher in the lycopene group and MDA levels were lower when compared with controls. ${ }^{106}$

\section{Bone health}

Oxidative stress, which has been shown to control the function of both osteoclasts and osteoblasts, may contribute to the pathogenesis of the skeletal system including the most prevalent metabolic disease, osteoporosis. A number of studies revealed that ROS increase bone resorption. Others suggested that ROS may be involved in the regulation of osteoclast formation and osteoclast motility. Limited studies demonstrated that lycopene had beneficial effects on bone health. ${ }^{107}$

Kim et al.108 (2002) showed that lycopene stimulated the proliferation of osteoblast-like SaOS-2 cells. On the other hand, Park et al.109 (1997) reported that lycopene had an inhibitory effect on the cell proliferation of MC3T3 cells, which are osteoblastic cells of lower species. However, both studies reported a stimulation of alkaline phosphatase activity. Rao et al. ${ }^{110}$ (2003) cultured cells from bone marrow prepared from rat femurs in 16-well calcium phosphate-coated OsteologicTM multi-test slides (Millenium Biologix Inc.). Varying concentrations of lycopene in the absence or presence of the resorbing agent $\mathrm{PTH}-(1-34)$ were added at the start of culture and at each medium change every 48 hours. Lycopene inhibited TRAP+ multinucleated cell formation in both vehicle- and PTHtreated cultures. The number of cells stained with the NBT reduction product formazan was decreased by treatment with $10^{-5} \mathrm{M}$ lycopene, indicating that lycopene inhibited the formation of ROS-secreting osteoclasts. ${ }^{110}$ Ishimi et al. ${ }^{111}$ (1999) in murine osteoclasts formed in coculture with calvarial osteoblasts. Furthermore, they could not demonstrate any effect of lycopene on bone resorption. ${ }^{111}$

\section{Other diseases}

Oxidative stress has been suggested as an important contributory factor in male infertility.112 Antioxidants for male infertility could potentially have a great impact on the management of couples with infertility. To date, a small number of studies have evaluated the role of vitamins and antioxidants (mostly as single agents) in male infertility, but additional studies are needed. ${ }^{10}$ Dawson et al. ${ }^{113}$ (1993) demonstrated the activity of vitamin $C$ on semen quality, and Geva et al.114 (1996) and Suleiman et al.115 (1996) showed the activity of vitamin $E$ on semen quality. Men with antibody-mediated infertility were found to have lower semen lycopene levels than fertile controls. ${ }^{116}$

Low serum levels of lycopene have also been associated with increased risk of psychiatric disorders. ${ }^{117}$

A study with 17 adults with asthma treated with placebo, tomato extract (Lyc-o-Mato ${ }^{\circledR}, 45 \mathrm{mg} /$ day lycopene), and tomato juice (45 mg/day of lycopene) for 7 days showed reduced airway neutrophil influx and reduced sputum neutrophil elastase activity after the tomato extract and tomato juice treatment. During placebo treatment, plasma lycopene concentrations decreased, the percentage of neutrophils increased, and neutrophil elastase levels increased.118

\section{CONCLUSION}

Diets rich in fruits and vegetables are associated with a lower risk of numerous diseases including cancers. Intake of fruits and vegetables that contain high levels of vitamins $C$ and $A$, phenolics, and carotenoids for reducing cancer risk have been made by several researchers.

Lycopene is one of the major carotenoids in Western diets, accounting for more than $50 \%$ of carotenoids in humans. A brief summary of the literature relating to lycopene and its role in health is presented in this article. Promising data from epidemiologic as well as cell culture and animal studies suggest that lycopene and the consumption of lycopene-containing foods may affect several chronic disorders. Nevertheless, more clinical data are needed to support this hypothesis. In addition, further detailed research is required to understand other beneficial health effects of lycopene and its mechanisms.

Conflict of Interest: No conflict of interest was declared by the authors.

\section{REFERENCES}

1. Rao YK, Geethangili M, Fang SH, Tzeng YM. Antioxidant and cytotoxic activities of naturally occurring phenolic and related compounds: a comparative study. Food Chem Toxicol. 2007;45:1770-1776.

2. Lima CF, Fernandes-Ferreira M, Pereira-Wilson C. Phenolic compounds protect HepG2 cells from oxidative damage: relevance of glutathione levels. Life Sci. 2006;79:2056-2068.

3. Halliwell B, Chirico S. Lipid peroxidation: its mechanism, measurement, and significance. Am J Clin Nutr. 1993;57(Suppl 5):715S-724S.

4. Rao A, Rao L. Lycopene and human health. Curr Top Nutraceutical Res. 2004;2:127-136.

5. Balasundram N, Sundram K, Samman S. Phenolic compounds in plants and agri-industrial by-products: Antioxidant activity, occurrence, and potential uses. Food Chem. 2006;99:191-203.

6. Bravo L. Polyphenols: chemistry, dietary sources, metabolism, and nutritional significance. Nutr Rev. 1998;56:317-333.

7. Alasalvar C, Grigor JM, Zhang D, Quantick PC, Shahidi F. Comparison of volatiles, phenolics, sugars, antioxidant vitamins, and sensory quality of different colored carrot varieties. J Agricul Food Chem. 2001;49:14101416.

8. Williams GM, Williams CL, Weisburger JH. Diet and cancer prevention: the fiber first diet. Toxicol Sci. 1999;52(Suppl 2):72-86.

9. Ignarro LJ, Balestrieri ML, Napoli C. Nutrition, physical activity, and cardiovascular disease: an update. Cardiovasc Res. 2007;73:326-340.

10. Rao AV, Ray MR, Rao LG. Lycopene. Adv Food Nutr Res. 2006;51:99-164.

11. Agarwal S, Rao AV. Carotenoids and chronic diseases. Drug Met Drug Interact. 2000;17:189-210.

12. Britton G, Liaaen-Jensen S, Pfander H. In: Carotenoids volume 5: nutrition and health, Ed(s): Springer Science \& Business Media, 2009. 
13. Boyacioglu M, Kum C, Sekkin S, Yalinkilinc HS, Avci H, Epikmen ET, Karademir $U$. The effects of lycopene on DNA damage and oxidative stress on indomethacin-induced gastric ulcer in rats. Clin Nutr. 2016;35:428-435.

14. Lucarini M, Lanzi S, D'Evoli L, Aguzzi A, Lombardi-Boccia G. Intake of vitamin $A$ and carotenoids from the Italian population results of an Italian total diet study. Int J Vit Nutr Res. 2006;76:103-109.

15. Porrini M, Riso P. What are typical lycopene intakes? J Nutr. 2005;135:2042S-2045S.

16. Story EN, Kopec RE, Schwartz SJ, Harris GK. An update on the health effects of tomato lycopene. Annu Rev Food Sci Technol. 2010;1:189-210.

17. Rao AV, Agarwal S. Bioavailability and in vivo antioxidant properties of lycopene from tomato products and their possible role in the prevention of cancer. Nutr Cancer. 1998;31:199-203.

18. Mellert W, Deckardt K, Gembardt C, Schulte S, Van Ravenzwaay B, Slesinski R. Thirteen-week oral toxicity study of synthetic lycopene products in rats. Food Chem Toxicol. 2002;40:1581-1588.

19. Jonker D, Kuper CF, Fraile N, Estrella A, Rodríguez Otero C. Ninety-day oral toxicity study of lycopene from Blakeslea trispora in rats. Regul Toxicol Pharmacol. 2003;37:396-406.

20. Michael McClain R, Bausch J. Summary of safety studies conducted with synthetic lycopene. Regul Toxicol Pharmacol. 2003;37:274-285.

21. Xianquan S, Shi J, Kakuda Y, Yueming J. Stability of lycopene during food processing and storage. J Med Food. 2005;8:413-422.

22. Gärtner C, Stahl W, Sies H. Lycopene is more bioavailable from tomato paste than from fresh tomatoes. Am J Clin Nutr. 1997;66:116-122.

23. Nguyen ML, Schwartz SJ. Lycopene: chemical and biological properties. Food technology (USA). 1999.

24. Rao AV, Waseem Z, Agarwal S. Lycopene content of tomatoes and tomato products and their contribution to dietary lycopene. Food Res Int. 1998;31:737-741.

25. Brown MJ, Ferruzzi MG, Nguyen ML, Cooper DA, Eldridge AL, Schwartz SJ, White WS. Carotenoid bioavailability is higher from salads ingested with full-fat than with fat-reduced salad dressings as measured with electrochemical detection. Am J Clin Nutr. 2004;80:396-403.

26. Unlu NZ, Bohn T, Clinton SK, Schwartz SJ. Carotenoid absorption from salad and salsa by humans is enhanced by the addition of avocado or avocado oil. J Nutr. 2005;135:431-436.

27. During A, Dawson HD, Harrison EH. Carotenoid transport is decreased and expression of the lipid transporters SR-BI, NPC1L1, and ABCA1 is downregulated in Caco-2 cells treated with ezetimibe. J Nutr. 2005;135:2305-2312.

28. Moussa M, Landrier JF, Reboul E, Ghiringhelli O, Coméra C, Collet X, Fröhlich K, Böhm V, Borel P. Lycopene absorption in human intestinal cells and in mice involves scavenger receptor class B type I but not Niemann-Pick C1-like 1. J Nutr. 2008;138:1432-1436.

29. Stahl W, Sies H. Lycopene: a biologically important carotenoid for humans? Arch Biochem Biophys. 1996;336:1-9.

30. Kun Y, Ssonko Lule U, Xiao-Lin D. Lycopene: Its Properties and Relationship to Human Health. Food Rev Int. 2006;22:309-333.

31. Khachik F, Carvalho L, Bernstein PS, Muir GJ, Zhao DY, Katz NB. Chemistry, distribution, and metabolism of tomato carotenoids and their impact on human health. Exp Biol Med (Maywood). 2002;227:845-851.

32. Clinton SK. Lycopene: chemistry, biology, and implications for human health and disease. Nutr Rev. 1998;56:35-51.
33. Sies H, Stahl W. Vitamins E and C, beta-carotene, and other carotenoids as antioxidants. Am J Clin Nutr. 1995,62(6 Suppl):1315S-1321S.

34. Agarwal S, Rao AV. Tomato lycopene and its role in human health and chronic diseases. CMAJ. 2000;163:739-744.

35. Tapiero H, Townsend DM, Tew KD. The role of carotenoids in the prevention of human pathologies. Biomed Pharmacother. 2004;58:100110.

36. Wertz K, Siler U, Goralczyk R. Lycopene: modes of action to promote prostate health. Arch Biochem Biophys. 2004:430:127-134.

37. Zhang LX, Cooney RV, Bertram JS. Carotenoids enhance gap junctional communication and inhibit lipid peroxidation in $\mathrm{C} 3 \mathrm{H} / 10 \mathrm{~T} 1 / 2$ cells: relationship to their cancer chemopreventive action. Carcinogenesis. 1991;12:2109-2114.

38. Matsushima-Nishiwaki R, Shidoji Y, Nishiwaki S, Yamada T, Moriwaki $\mathrm{H}$, Muto $\mathrm{Y}$. Suppression by carotenoids of microcystin-induced morphological changes in mouse hepatocytes. Lipids. 1995;30:10291034.

39. Fuhrman B, Elis A, Aviram M. Hypocholesterolemic effect of lycopene and beta-carotene is related to suppression of cholesterol synthesis and augmentation of LDL receptor activity in macrophages. Biochem Biophys Res Commun. 1997;233:658-662.

40. Chew BP, Park JS. Carotenoid action on the immune response. J Nutr. 2004;134:257S-261S.

41. Kim GY, Kim JH, Ahn SC, Lee HJ, Moon DO, Lee CM, Park YM. Lycopene suppresses the lipopolysaccharide-induced phenotypic and functional maturation of murine dendritic cells through inhibition of mitogenactivated protein kinases and nuclear factor-kappaB. Immunology. 2004:113:203-211.

42. Giovannucci E, Rimm EB, Liu Y, Stampfer MJ, Willett WC. A prospective study of tomato products, lycopene, and prostate cancer risk. J Natl Cancer Inst. 2002;94:391-398.

43. Colditz GA, Branch LG, Lipnick RJ, Willett WC, Rosner B, Posner BM, Hennekens $\mathrm{CH}$. Increased green and yellow vegetable intake and lowered cancer deaths in an elderly population. Am J Clin Nutr. 1985;41:32-36.

44. Franceschi S, Bidoli E, La Vecchia C, Talamini R, D'Avanzo B, Negri E. Tomatoes and risk of digestive-tract cancers. Int J Cancer. 1994;59:181184.

45. La Vecchia C. Mediterranean epidemiological evidence on tomatoes and the prevention of digestive-tract cancers. Proc Soc Exp Biol Med. 1998;218:125-128.

46. Velmurugan B, Bhuvaneswari V, Burra UK, Nagini S. Prevention of $\mathrm{N}$-methyl-N'-nitro-N-nitrosoguanidine and saturated sodium chlorideinduced gastric carcinogenesis in Wistar rats by lycopene. Eur J Cancer Preve. 2002;11:19-26.

47. Palozza P, Simone R, Catalano A, Boninsegna A, Böhm V, Fröhlich K, Mele MC, Monego G, Ranelletti FO. Lycopene prevents 7-ketocholesterolinduced oxidative stress, cell cycle arrest and apoptosis in human macrophages. J Nutr Biochem. 2010;21:34-46.

48. Rao LG, Mackinnon ES, Josse RG, Murray TM, Strauss A, Rao AV. Lycopene consumption decreases oxidative stress and bone resorption markers in postmenopausal women. Osteoporosis Int. 2007;18:109-115.

49. Palozza $P$, Colangelo $M$, Simone R, Catalano A, Boninsegna A, Lanza P, Monego G, Ranelletti FO. Lycopene induces cell growth inhibition by altering mevalonate pathway and Ras signaling in cancer cell lines. Carcinogenesis. 2010;31:1813-1821. 
50. Velmurugan B, Mani A, Nagini S. Combination of S-allylcysteine and lycopene induces apoptosis by modulating $\mathrm{Bcl}-2, \mathrm{Bax}, \mathrm{Bim}$ and caspases during experimental gastric carcinogenesis. Eur J Cancer Prev. 2005;14:387-393.

51. Khan N, Afaq F, Mukhtar H. Apoptosis by dietary factors: the suicide solution for delaying cancer growth. Carcinogenesis. 2006;28:233-239.

52. Zhang B, Gu Y. Low expression of ERK signaling pathway affecting proliferation, cell cycle arrest and apoptosis of human gastric HGC-27 cells line. Mol Biol Rep. 2014;41:3659-3669.

53. Liu C, Russell RM, Wang XD. Lycopene supplementation prevents smokeinduced changes in p53, p53 phosphorylation, cell proliferation, and apoptosis in the gastric mucosa of ferrets. J Nutr. 2006;136:106-111.

54. Hall AK. Liarozole amplifies retinoid-induced apoptosis in human prostate cancer cells. Anticancer Drugs. 1996;7:312-320.

55. Kotake-Nara E, Kushiro M, Zhang H, Sugawara T, Miyashita K, Nagao A. Carotenoids affect proliferation of human prostate cancer cells. J Nutr. 2001;131:3303-3306.

56. Kim L, Rao AV, Rao LG. Effect of lycopene on prostate LNCaP cancer cells in culture. J Med Food. 2002;5:181-187.

57. Boileau TW, Liao Z, Kim S, Lemeshow S, Erdman JW Jr, Clinton SK. Prostate carcinogenesis in N-methyl-N-nitrosourea (NMU)-testosteronetreated rats fed tomato powder, lycopene, or energy-restricted diets. J Nat Cancer Inst. 2003;95:1578-1586.

58. Mills PK, Beeson WL, Phillips RL, Fraser GE. Cohort study of diet, lifestyle, and prostate cancer in Adventist men. Cancer. 1989;64:598604.

59. Jeong Y, Lim JW, Kim H. Lycopene Induces Apoptosis in Pancreatic Cancer Cells. The FASEB Journal 30 (1 Supplement), 691.623-691.623, 2016.

60. Crew KD, Neugut Al. Epidemiology of gastric cancer. World J Gastroenterol. 2006;12:354-362.

61. Tsugane S, Sasazuki S. Diet and the risk of gastric cancer: review of epidemiological evidence. Gastric Cancer. 2007;10:75-83.

62. Persson C, Sasazuki S, Inoue M, Kurahashi N, Iwasaki M, Miura T, Ye W, Tsugane S; JPHC Study Group. Plasma levels of carotenoids, retinol and tocopherol and the risk of gastric cancer in Japan: a nested case-control study. Carcinogenesis. 2008;29:1042-1048.

63. Jenab M, Riboli E, Ferrari P, Friesen M, Sabate J, Norat T, Slimani N, Tjønneland A, Olsen A, Overvad K, Boutron-Ruault MC, Clavel-Chapelon $F$, Boeing $H$, Schulz M, Linseisen J, Nagel G, Trichopoulou A, Naska A, Oikonomou E, Berrino F, Panico S, Palli D, Sacerdote C, Tumino R, Peeters PH, Numans ME, Bueno-de-Mesquita HB, Büchner FL, Lund E, Pera G, Chirlaque MD, Sánchez MJ, Arriola L, Barricarte A, Quirós JR, Johansson I, Johansson A, Berglund G, Bingham S, Khaw KT, Allen N, Key T, Carneiro F, Save V, Del Giudice G, Plebani M, Kaaks R, Gonzalez CA. Plasma and dietary carotenoid, retinol and tocopherol levels and the risk of gastric adenocarcinomas in the European prospective investigation into cancer and nutrition. Br J Cancer. 2006;95:406-415.

64. Nomura AM, Hankin JH, Kolonel LN, Wilkens LR, Goodman MT, Stemmermann GN. Case-control study of diet and other risk factors for gastric cancer in Hawaii (United States). Cancer Causes Control. 2003;14:547-558.

65. Graham S, Haughey B, Marshall J, Brasure J, Zielezny M, Freudenheim J, West D, Nolan J, Wilkinson G. Diet in the epidemiology of gastric cancer. Nutr Cancer. 1990;13:19-34.
66. Correa P, Fontham E, Pickle LW, Chen V, Lin YP, Haenszel W. Dietary determinants of gastric cancer in south Louisiana inhabitants. J Nat Cancer Inst. 1985;75:645-654.

67. Haenszel W, Kurihara M, Segi M, Lee RK. Stomach cancer among Japanese in Hawaii. J Nat Cancer Inst. 1972;49:969-988.

68. Tajima K, Tomina S. Dietary habits and gastro-intestinal cancers: a comparative case-control study of stomach and large intestinal cancers in Nagoya, Japan. Jpn J Cancer Res. 1985;76:705-716.

69. Modan B, Cuckle H, Lubin F. A note on the role of dietary retinol and carotene in human gastro-intestinal cancer. Int J Cancer. 1981;28:421424.

70. Buiatti E, Palli D, Decarli A, Amadori D, Avellini C, Bianchi S, Biserni R, Cipriani F, Cocco P, Giacosa A, Marubini M, Puntoni R, Vindigni C, Fraumeni Jr J, Blot W. A case-control study of gastric cancer and diet in Italy. Int J Cancer. 1989;44:611-616.

71. Ramón JM, Serra L, Cerdó C, Oromí J. Dietary factors and gastric cancer risk. A case-control study in Spain. Cancer. 1993;71:1731-1735.

72. González CA, Sanz JM, Marcos G, Pita S, Brullet E, Saigi E, Badia A, Riboli E. Dietary factors and stomach cancer in Spain: a multi-centre case-control study. Int J Cancer. 1991;49:513-519.

73. Boeing H, Jedrychowski W, Wahrendorf J, Popiela T, Tobiasz-Adamczyk $B$, Kulig A. Dietary risk factors in intestinal and diffuse types of stomach cancer: a multicenter case-control study in Poland. Cancer Causes Control. 1991;2:227-233.

74. Tuyns AJ, Kaaks R, Haelterman M, Riboli E. Diet and gastric cancer. A case-control study in Belgium. Int J Cancer. 1992;51:1-6.

75. Hansson LE, Nyrén O, Bergström R, Wolk A, Lindgren A, Baron J, Adami $\mathrm{HO}$. Diet and risk of gastric cancer. A population-based case-control study in Sweden. Int J Cancer. 1993;55:181-189.

76. La Vecchia C, Negri E, Decarli A, D’Avanzo B, Franceschi S. A casecontrol study of diet and gastric cancer in northern Italy. Int $\mathrm{J}$ Cancer. 1987:40:484-489.

77. Tsugane S, Tsuda M, Gey F, Watanabe S. Cross-sectional study with multiple measurements of biological markers for assessing stomach cancer risks at the population level. Environ Health Perspect. 1992;98:207-210.

78. Ito Y, Kurata M, Hioki R, Suzuki K, Ochiai J, Aoki K. Cancer mortality and serum levels of carotenoids, retinol, and tocopherol: a populationbased follow-up study of inhabitants of a rural area of Japan. Asian Pac J Cancer Prev. 2005;6:10-15.

79. Cui Y, Shikany JM, Liu S, Shagufta Y, Rohan TE. Selected antioxidants and risk of hormone receptor-defined invasive breast cancers among postmenopausal women in the Women's Health Initiative Observational Study. Am J Clin Nutr. 2008;87:1009-1018.

80. Ito Y, Wakai K, Suzuki K, Ozasa K, Watanabe Y, Seki N, Ando M, Nishino Y, Kondo T, Ohno Y, Tamakoshi A; JACC Study Group. Lung cancer mortality and serum levels of carotenoids, retinol, tocopherols, and folic acid in men and women: a case-control study nested in the JACC Study. J Epidemiol. 2005;15(Suppl 2):S140-S149.

81. Satia JA, Littman A, Slatore CG, Galanko JA, White E. Long-term use of beta-carotene, retinol, lycopene, and lutein supplements and lung cancer risk: results from the VITamins And Lifestyle (VITAL) study. Am J Epidemiol. 2009;169:815-828.

82. Kochanek KD, Murphy SL, Anderson RN, Scott C. Deaths: final data for 2002. Natl Vital Stat Rep. 2004;53:1-115. 
83. Rao AV. Lycopene, tomatoes, and the prevention of coronary heart disease. Exp Biol Med (Maywood). 2002;227:908-913.

84. Wolak T, Paran E. Can carotenoids attenuate vascular aging? Vascul Pharmacol. 2013;59:63-66.

85. Zou ZY, Xu XR, Lin XM, Zhang HB, Xiao X, Ouyang L, Huang YM, Wang X, Liu YQ. Effects of lutein and lycopene on carotid intima-media thickness in Chinese subjects with subclinical atherosclerosis: a randomised, double-blind, placebo-controlled trial. Brit J Nutr. 2014;111:474-480.

86. Agarwal S, Rao AV. Tomato lycopene and low density lipoprotein oxidation: a human dietary intervention study. Lipids. 1998;33:981-984.

87. Hadley CW, Clinton SK, Schwartz SJ. The consumption of processed tomato products enhances plasma lycopene concentrations in association with a reduced lipoprotein sensitivity to oxidative damage. $J$ Nutr. 2003;133:727-732.

88. Shen YC, Chen SL, Wang CK. Contribution of tomato phenolics to antioxidation and down-regulation of blood lipids. J Agricul Food Chem. 2007;55:6475-6481.

89. Bohn T, Blackwood M, Francis D, Tian Q, Schwartz SJ, Clinton SK. Bioavailability of phytochemical constituents from a novel soy fortified lycopene rich tomato juice developed for targeted cancer prevention trials. Nutr Cancer. 2013;65:919-929.

90. Halliwell B. Role of free radicals in the neurodegenerative diseases: therapeutic implications for antioxidant treatment. Drugs Aging. 2001;18:685-716.

91. Retz W, Gsell W, Münch G, Rösler M, Riederer P. In: Free radicals in Alzheimer's disease, Ed(s): Springer, 1998.

92. Kaur H, Chauhan S, Sandhir R. Protective effect of lycopene on oxidative stress and cognitive decline in rotenone induced model of Parkinson's disease. Neurochem Res. 2011;36:1435-1443.

93. Qu M, Li L, Chen C, Li M, Pei L, Chu F, Yang J, Yu Z, Wang D, Zhou Z. Protective effects of lycopene against amyloid $\beta$-induced neurotoxicity in cultured rat cortical neurons. Neurosci Lett. 2011;505:286-290.

94. Sandhir R, Mehrotra A, Kamboj SS. Lycopene prevents 3-nitropropionic acid-induced mitochondrial oxidative stress and dysfunctions in nervous system. Neurochem Int. 2010;57:579-587.

95. Qu M, Zhou Z, Chen C, Li M, Pei L, Chu F, Yang J, Wang Y, Li L, Liu C, Zhang L, Zhang G, Yu Z, Wang D. Lycopene protects against trimethyltininduced neurotoxicity in primary cultured rat hippocampal neurons by inhibiting the mitochondrial apoptotic pathway. Neurochem Int. 2011;59:1095-1103.

96. Panda V, Sonkamble M. Anti-ulcer activity of Ipomoea batatas tubers (sweet potato). Func Foods Health Disease. 2012;2:48-61.

97. Han RM, Zhang JP, Skibsted LH. Reaction dynamics of flavonoids and carotenoids as antioxidants. Molecules. 2012;17:2140-2160.

98. Jain D, Katti N. Combination treatment of lycopene and hesperidin protect experimentally induced ulcer in laboratory rats. J Intercul Ethnopharmacol. 2015;4:143-146.

99. Conn PF, Schalch W, Truscott TG. The singlet oxygen and carotenoid interaction. J Photochem Photobiol B. 1991;11:41-47.

100. Jang SH, Lim JW, Morio T, Kim H. Lycopene inhibits Helicobacter pylori-induced ATM/ATR-dependent DNA damage response in gastric epithelial AGS cells. Free Radic Biol Med. 2012;52:607-615.

101. Karemore TV, Motwani M. Evaluation of the effect of newer antioxidant lycopene in the treatment of oral submucous fibrosis. Indian J Dent Res. 2012;23:524-528.
102. Shidfar F, Agah S, Ekhlasi G, Salehpour A, Ghourchian S. Lycopene an adjunctive therapy for Helicobacter pylori eradication: a quasi-control trial. J Complement Integr Med. 2012;9:14.

103. Milani C, Maccari M, Mosconi P. Action of lycopene in the experimental gastric ulcer. Pharmacology. 1970;4:334-340.

104. Locke GR 3rd, Talley NJ, Fett SL, Zinsmeister AR, Melton LJ 3rd. Prevalence and clinical spectrum of gastroesophageal reflux: a population-based study in Olmsted County, Minnesota. Gastroenterology. 1997:112:1448-1456.

105. Jiménez P, Piazuelo E, Sánchez MT, Ortego J, Soteras F, Lanas A. Free radicals and antioxidant systems in reflux esophagitis and Barrett's esophagus. World J Gastroenterol. 2005;11:2697-2703.

106. Giri AK, Rawat JK, Singh M, Gautam S, Kaithwas G. Effect of lycopene against gastroesophageal reflux disease in experimental animals. BMC Complement Altern Med. 2015;15:110.

107. Rao LG, Guns E, Rao AV. Lycopene: its role in human health and disease. Agro Food. 2003;7:25-30.

108. Kim L, Rao AV, Rao LG. Lycopene II effect on osteoblasts: the carotenoid lycopene stimulates cell proliferation and alkaline phosphatase activity of SaOS-2 cells. J Med Food. 2003;6:79-86.

109. Park CK, Ishimi Y, Ohmura M, Yamaguchi M, Ikegami S. Vitamin A and carotenoids stimulate differentiation of mouse osteoblastic cells. J Nutr Sci Vitaminol (Tokyo). 1997;43:281-296.

110. Rao LG, Krishnadev N, Banasikowska K, Rao AV. Lycopene I effect on osteoclasts: lycopene inhibits basal and parathyroid hormonestimulated osteoclast formation and mineral resorption mediated by reactive oxygen species in rat bone marrow cultures. J Med Food. 2003;6:69-78.

111. Ishimi Y, Ohmura M, Wang X, Yamaguchi M, Ikegami S. Inhibition by carotenoids and retinoic acid of osteoclast-like cell formation induced by bone-resorbing agents in vitro. J Clin Biochem Nutr. 1999;27:113-122.

112. Zini A, de Lamirande $E$, Gagnon C. Reactive oxygen species in semen of infertile patients: levels of superoxide dismutase- and catalase-like activities in seminal plasma and spermatozoa. Int J Androl. 1993;16:183188.

113. Dawson VL, Dawson TM, Bartley DA, Uhl GR, Snyder SH. Mechanisms of nitric oxide-mediated neurotoxicity in primary brain cultures. J Neurosci. 1993;13:2651-2661.

114. Geva E, Bartoov B, Zabludovsky N, Lessing JB, Lerner-Geva L, Amit A. The effect of antioxidant treatment on human spermatozoa and fertilization rate in an in vitro fertilization program. Fertil Steril. 1996;66:430-434.

115. Suleiman SA, Ali ME, Zaki ZM, el-Malik EM, Nasr MA. Lipid peroxidation and human sperm motility: protective role of vitamin E. J Androl. 1996;17:530-537.

116. Palan $P, N a z$ R. Changes in various antioxidant levels in human seminal plasma related to immunoinfertility. Arch Androl. 1996;36:139-143.

117. Li Y, Zhang J. Serum concentrations of antioxidant vitamins and carotenoids are low in individuals with a history of attempted suicide. Nutr Neurosci. 2007;10:51-58.

118. Wood LG, Garg ML, Powell H, Gibson PG. Lycopene-rich treatments modify noneosinophilic airway inflammation in asthma: proof of concept. Free Radical Res. 2008;42:94-102. 